\title{
The Innovation and Practice of the Managerial Accounting Talents Training Mode in Higher Vocational College
}

\author{
Jing Wang \\ School of Accounting, Chongqing Business Vocational College, Chongqing, 401331, China
}

Keywords: Managerial accounting; Vocational colleges; Talent training; Innovation; Practice

\begin{abstract}
With the development of China's social economy and the modernization and internationalization of enterprise management, the demand for traditional accounting talents will gradually decrease. However, the more and more demand for "managerial" accounting talents, and the structural shortage of accounting talents will become increasingly acute. As an important base for talent training, colleges and universities should actively uphold the purpose of education serving the economic and social development. Moreover, colleges and universities will combine education with economic and social development needs, focusing on training managerial accounting talents, so that to reduce the risk of college student's entrepreneurship and promote innovation and entrepreneurship of college students. Based on the author's teaching and practical experience, this paper first analyzed the necessity of the training of "managerial" accounting talents, and then put forward the implementation path of training managerial accounting talents.
\end{abstract}

\section{Introduction}

The training of applied talents needs to realize the coordinated development of knowledge, ability and quality, in which practical teaching is an important way to consolidate knowledge, improve ability and internalize quality. With the goal of higher vocational education, training of accounting professional ability is determined: We take the basic ability training as the foundation, taking the comprehensive quality training as the core, taking the innovation spirit education as the main line with constructing the reasonable, perfect and systematic practice teaching. This can really make the professional students equipped with accounting, analysis, management, innovation ability, and are familiar with the accounting practice of small and medium sized enterprises. Further, we can cultivate managerial accounting talents who are good at using accounting information to participate in enterprise management and decision making. At present, the demand structure of accounting talents in our country has begun to change, and the demand for managerial accounting talents is increasing. This also puts forward new requirements for our current accounting talents training mode. Therefore, we believe that the training goal of accounting specialty in colleges and universities is an inevitable trend from the "accounting" to "managerial" accounting talents. How to cultivate the applied talents in managerial accounting to meet the needs of the modern has become an important topic of current accounting education.

\section{The Necessity of the Training of "Managerial" Accounting Talents}

The society needs "managerial" senior accounting talents. With the world economic integration, the expansion of business scale and business competition intensifies and enterprises are in urgent need of accounting talents to participate in the production and operation of the enterprise daily management and strategic management. Accounting talents who are proficient in accounting policies, and familiar with international practices and master business management knowledge with the strategic vision of enterprise development are the indispensable talents for enterprise development. In the fierce competition in the market, if the lack of such a "steward" do financial management, expenditure, capital management and financial risk control, the ability of enterprises 
to pursue economic benefits will be directly affected, and the sustainable development ability of enterprises will be challenged. It is also the case, in recent years, there is no doubt that proficient in accounting and management of complex finance talents can become China's market darling of the accounting talents.

Improve students' employment competitiveness. At present, the "operational" accounting talents engaged in accounting work in enterprises are in the majority. "professional managerial" accounting talents engaged in financial management, accounting management, tax management, cost management and internal control work are becoming less. However, "comprehensive managerial" accounting talents participate in enterprise integration and comprehensive management as accountants are less than "professional managerial" accounting talents. Thus, enterprises urgently need accountants to participate in the production management, daily management and strategic management of enterprises. Beijing, Shanghai, Guangdong and other major city talents recruitment results show that: The needs of "managerial" accounting talents like "professional management" and "comprehensive managerial" are increasing. "Managerial" accounting talents proficient in accounting and management have become the popular talents in the talent market across the country.

The need to clarify the characteristics of accounting specialty in our university. In the fierce competition in the quality of running colleges and universities, the accounting profession of our school cannot blindly compare with the well-known accounting major in finance and economics universities in china. Strengthening the characteristic construction of accounting specialty is an important competitive strategy for our accounting major to survive and develop under the new situation of popularization of higher education. With the development of economy and society, the demand for talents shows diversity and multi-level trend. Only colleges and universities grasp the characteristics and trends of this demand and cultivate talents, can they achieve a win-win situation between schools and society. In recent years, on the basis of fully investigating the social demand, and the background of accounting profession and its development trend with giving full play to the teaching resources and ability advantage of our school's economic management discipline, we have updated the concept of school and professional construction concept, establish a clear training goal and scientific and reasonable training plan, strengthen the construction of teaching staff, make reasonable allocation of teaching facilities and library materials to carry out the construction of courses and teaching materials according to the school running history, and social reputation of our school, especially the characteristic foundation that has been accumulated in the history of running school focusing on the training goal of "managerial" accounting talents.

\section{The Implementation Path of Training Managerial Accounting Talents}

Setting curriculum system reasonably. The college and university should continue to promote the construction of curriculum system, hierarchical design basic courses, professional courses and professional practice curriculum theory. We should optimize the curriculum system and improve the talent training mode. The training of managerial accounting talents not only includes accounting professional ability, but also includes other basic business literacy related to management accounting. In the basic courses, when arranging courses such as management, organizational behavior and enterprise resource planning, we can appropriately set up entrepreneurship courses, so as to lay the foundation of business knowledge for students; the theory of curriculum should include the relevant accounting courses, financial management and cost accounting and other basic accounting courses. On this basis, we set up managerial accounting course, and reasonably coordinated the overlapping content between courses. Managerial accounting with cost accounting and repeated content of financial management can adopt a simplified way of teaching. Management accounting unique content can be regarded as the focus of teaching. The implementation of bilingual teaching of management accounting can not only broaden the students' thinking, but also improve their reading ability in foreign languages. Therefore, colleges and universities should constantly improve and explore the managerial accounting teaching contents and teaching methods, and design the managerial accounting talents training courses, and gradually increase the proportion 
of the managerial accounting curriculum, so that to establish the goal of cultivating talents of managerial accounting curriculum system.

Pay attention to case teaching. The case teaching of management accounting is a teaching method which organically combines management accounting theory with enterprise management practice. This can not only strengthen students' understanding of management accounting theory knowledge, but also improve students' ability to use knowledge effectively. The real business case can make students understand the management status through the case analysis of the enterprise based on it. Moreover, they can make analysis and countermeasures of management accounting problems, and learn the advanced experience of management accounting. The case analysis can take the ways of group discussion, reporting and teaching combination. This teaching mode can enhance the interaction between teachers and students to carry out the heuristic teaching and promote students basic ability into occupation ability with cultivating students' innovation ability on the basis of it. Management accounting teaching case should have certain fresh activity. The business environment is changing day by day, and the management accounting problem faced by enterprise is not invariable. Therefore, universities need to keep pace with the times, and make extensive collection of case resources of different industries and different operation mode of enterprise, so that to establish management accounting case teaching needs and expand the breadth and depth of students management accounting information with cultivating the students to find problems and the ability to analyze and solve problems.

Strengthening the construction of teaching staff. High quality teachers is a powerful guarantee for the management accounting talents training, so colleges and universities should actively promote the construction of management accounting teachers. Introduction of the internal culture and external culture, strengthening the management of accounting teachers and striving to create a professional skills and practical management of accounting staff and research team are what we want to achieved. On the one hand, we should actively "go out", and positively output potential teachers to make further study. We should encourage the experienced teacher to enter the university, accept new knowledge for scientific research institutes to update knowledge and enhance the theoretical level; Or we should go to different industries and different types of enterprises to carry out research cooperation. We can make teachers obtain first-hand data with achievements in scientific research, and can help enterprises to solve the problems of management accounting through the cooperation between university management accounting teachers and financial departments. On the other hand, "Introduction" is needed to build a practical tutor team. Colleges and universities should actively employ experts and scholars from different fields, such as excellent teachers from famous universities, chief accountant or chief financial officer of large enterprises and institutions, and so on as practical instructors for students. Practice instructors can enter the classroom to give accounting practice, and theory of teacher lectures can jointly organize classroom teaching; in class, they van help students to make occupation career planning reasonable accounting and participate in the practice of teaching materials, so that students master the practice of accounting business processing and accounting management methods. In addition, universities should actively promote the integration of research, and the enterprise should establish management accounting practices talent training base, so that to provide practical training opportunities for students. Students can make the accounting management of universities to meet the actual needs. Moreover, this can also help enterprises to improve the management level of accounting work to achieve a win-win situation of supply and demand of talents of management accounting.

\section{Summary}

The proportion of college students venture increased year by year, and management accounting has also ushered in the golden age of development. On the basis of the basic quality and ability of accounting talents, management accounting talents highlight the cultivation of students' practical ability and innovation ability. Training managerial accounting talents can provide professional accounting talents for the entrepreneurial team, and help to strengthen the management of venture enterprises, so that to improve the ability of risk identification and control and help the development 
of entrepreneurial enterprises. University, as an important base of management accounting personnel training, should seize the important historical opportunity with the integration of teaching resources, optimizing curriculum system and making reasonable arrangement of teaching content, so that to construct the high level management accounting team of teachers and train accounting talents management to meet the business enterprise development.

\section{Acknowledgement}

Foundation project: the key project of teaching reform in Higher Education in Chongqing: The Innovation and Practice of the Managerial Accounting Talents Training Mode in Higher Vocational College(162088).

Project author: Jing Wang

\section{References}

[1] Qiu Yizheng, Fan Xiaoqi. Cultivation of Management Accounting Talents and Reform of Accounting Experiment Teaching[J]. Accounting Friend, 2014, (26): 110-112.

[2] Qiu Yizheng. Cultivation of Management Accounting Talents and Reform of Accounting Experiment Teaching[J]. Chinese Accounting Society Accounting Education Specialized Committee. Chinese Accounting Society Accounting Education Specialized Committee 2014 Annual Meeting and the Seventh Accounting School Dean Forum Thesis[C]. China Accounting Institute of Accounting Education: Specialized Committee, 2014:4.

[3] Yizheng Qiu, Xu Yongbin. Research on Excellent Accounting Talents Training Mode Based on Management Characteristics[J]. Business Accounting, 2014, (02): 118-120.

[4] Wang Wenhua. Discussion on the Training of Managerial Accounting Talents[J]. Forum on Education, 2013, (41): 153-154

[5] Shen Xiaoyu. A Brief Analysis of "managerial" Accounting Talent Training[J]. Science and Technology Wind, 2013, (16): 237.

[6] Liu Yuhui, Yu Shanbo, Wang Linlin. Wang Linlin. Construction of Practical Teaching System for Management Oriented Accounting Talent Training[J]. Chinese and Foreign Enterprisers, 2013, (09): 206-207+214.

[7] Zhong Zhenqiang, Song Danbing. Reflections on the Innovation of Training Mode of Management Accounting Talents[J]. Gansu Agriculture, 2010, (04): 72-73. 